\title{
Transformation of Berber Traditional Planning and Living Spaces
}

\author{
${ }^{*}$ Dr. ASMAA SAADA 1 (D), Dr. DJAMEL DEKOUMI 2 (i) \\ 1 Faculty of Architecture, University Hadj LAkhdar, Batna \\ 2 Faculty of Architecture, University Salah BOUBNIDER, Constantine \\ E maill: luminaria.cos@hotmail.fr Email2: dj.dekoumi@gmail.com
}

\section{A R T I C LE I N F O:}

Article history:

Received 05 May 2018

Accepted 25 May 2018

Available online 26 September 2018

Keywords:

Social structure;

Urban growth;

Transformation of

planning;

Berber housing;

This work is licensed under a Creative Commons Attribution - NonCommercial - NoDerivs 4.0. "CC-BY-NC-ND"

\section{A B S T R A C T}

Most The Algerian Berber region was animated by a network of human settlements built according to the urban model of the Islamic medina and its traditional habitat of adobe. Various rural and urban development and transformation of planning and living spaces have recently come under the pressure of rapid urban growth. This study aims to analyze and compare Berber domestic spaces across a sample of houses from Aures valley, this region of Algeria which presents distinctive geological, geographical and historical characteristics. The study will look, first at the houses, then at similarities and differences in space configuration in order to pose questions of how this traditional architecture with its climatic and cultural solutions could be utilized or transplanted in the new urban context. The study focuses particularly on observing and analyzing different factors which influence urban life like social patterns, family lifestyle, migration which may have led to some modifications in the social structure. This attempt to analyse and compare the physical structure of Berber housing and settlements in Algeria might help to better understand the planning space organization and give us clues to the formulation of communities in the past; their culturally and climatically significant design methodology has considerable relevance to contemporary architecture. This study attempts to learn how the traditional Berber built environment may be considered as a good example of an end product of an interaction between constant elements such as the religious factors, the climate, the landscape and changeable elements such as economic, technological and industrial means, that is to say a product of a societal process.

JOURNAL OF CONTEMPORARY URBAN AFFAIRS (2019), 3(2), 28-34.

https://doi.org/10.25034/ijcua.2018.4698

www.ijcua.com

Copyright (c) 2018 Journal Of Contemporary Urban Affairs. All rights reserved.

\section{Introduction}

Traditional built environment is, essentially, a manifestation of the group. It is the result of a collective social code responding to basic needs, a shelter to ensure physical well-being, satisfactory comfort, security, while at the same
*Corresponding Author:

Faculty of Architecture, University Hadj LAkhdar, Batna E-mail address: luminaria.cos@hotmail.fr 
time responding to society's common respect and preservation of its natural environment. The house is the center of the society; a built-up space in which all the functions of this very society intermingle and present themselves, and in order to establish a better understanding of the habitat, it is imperative to apprehend all its aspects. This research focuses on the traditional habitat grouped and perched in some agglomerations of the Aures massif; it is a vast mountainous region of around $11,000 \mathrm{sq} . \mathrm{km}$, situated in the northeastern part of Algeria between the high plains and the Saharan borders. Whose approach is to establish a typology of this type of traditional habitat, highlighting main factors and several logics that have brought about the architectural and morphological transformations. The degradation and dilapidation of houses are mainly due to social and economic changes. This study aims to examine vernacular housing forms in the Aures valley to identify the common characteristics, which may better explain the factors of transformation in the domestic spaces in this very region. In addition, self-builders have been utilizing "Alien" house-design components in their projects. This new housing does not fulfill residents' social and cultural requirements, such as their need for privacy. New house designs were needed, based on the main traditional requirements of daily life, as adapted to modern.

\section{Physical aspect of the Aures massif}

The Aures massif is subdivided into Aures Chergui (eastern) and Aures Gharbi (western), and is characterized by the two deep and parallel valleys of Wadi El-Abiod and Wadi Abdi. It has a continental climate, which shows wide variation, with a very cold winter and hot summer (Figure. 1).

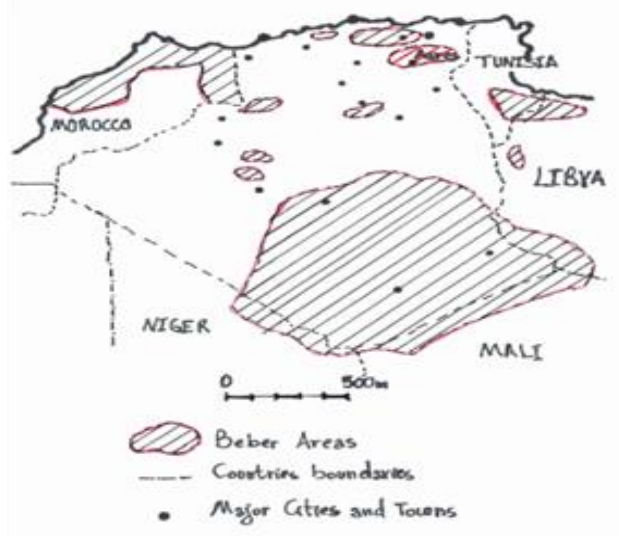

The physical aspect of the region is uneven, with rocky surfaces and very steep slopes. In addition to that, the aridity of climate and scarcity of water do not even allow the practice of cereal culture. Therefore, for economic reasons the inhabitants of the Aures valleys built their villages on the top of the hills and cliffs, Villages are thus composed of a series of separate living areas corresponding to the separate clan groupings, each with its own territory (Figure. 2). Whatever the environmental constraints, the choice of a site for a house is based on social criteria and on fundamental economic and cultural factors. The house is a social and economic unit, within which the disposition of the numerous spaces is intimately related to the structure of the family and the way it lives.

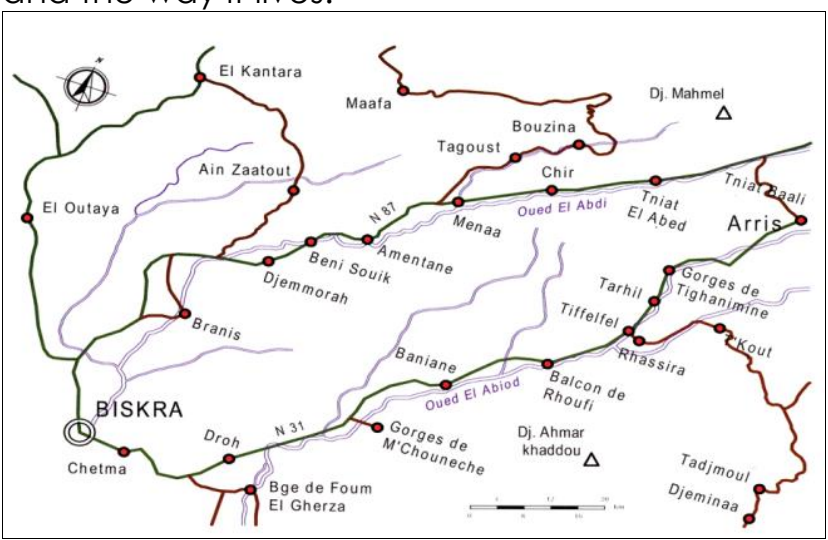

Figure 2. Localization of the Study area in the Aures valley. (N. Meghraoui Chouguiat. 2011).

\section{Factors of Transformation Berber Housing} Forms.

\section{1. Environmental Factors}

In some other cases; environmental conditions may be more influential than sociocultural factor which is the instance of Berber housing. Important factor dictating the location of Shawia settlements has been the lack of water and fertile land. This forced local population to build their villages on top of hills and cliffs in order to save lands for agriculture, as well as to protect themselves from the flooding of rivers. Formerly, this strategic position taken by the "Shawia" had a social and political reason during inter-tribal wars. In the Aures region the houses are generally grouped in hamlets and villages which high up on the mountains, established there for defensive purposes such as the community of Menaa (Figure. 3).

Figure 1. Map showing Berber area hatched. LEBBAL drawings.1989 (Developed by Authors). 


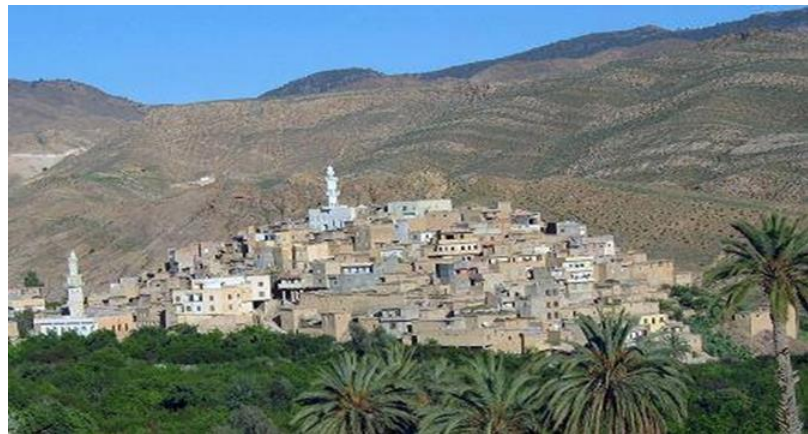

Figure 3. Menaa, Defensive Site. (Authors, 2017).

One of the most marked characteristics of these settlements is the singular unity of their architectural form. Taking advantage of the Cliffside by using the rock as a back wall, the houses, punctuated by a few small windows, are tailored to individual needs. Their juxtaposition produces a remarkable effect, creating villages of real character with a harmony due to the restricted range of materials and colors (Figure 4), and a unity due to related forms.

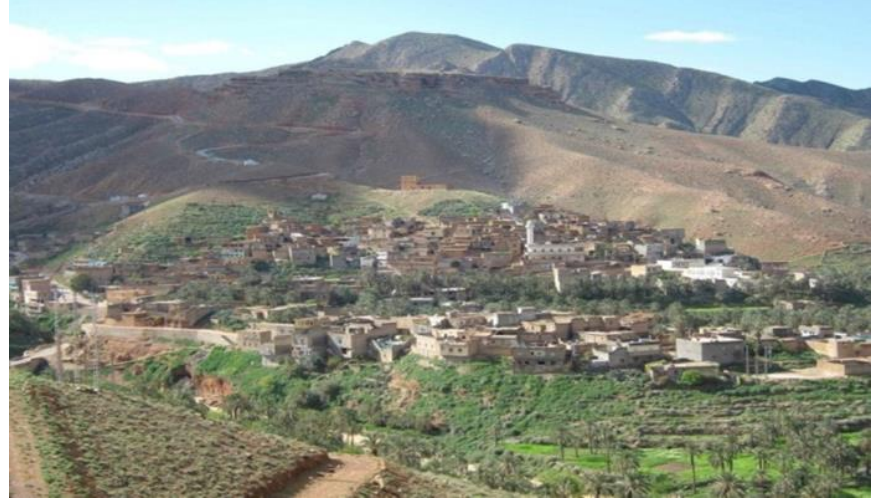

Figure 4. Warka, a typical Berber village. (Authors, 2017).

\subsection{The Social Structure}

There were two different types of tribal organization in pre-colonial Maghrib. In the first case several villages inhabited by sedentary farmers formed a tribe, or "arsh in Berber. Every tribe descended from a common mythical ancestor. It possessed a waste common territory also called 'arsh. The tribe was ruled by a military chief ('amin ul-'umana') elected every year by the council of elders, called jema'a, which was composed of representatives of the villages. It represented the highest judicial power of the tribe. During wars and political troubles many tribes formed military and political coalitions so-called taqbilt. This kind of tribal organization was observed in Berber villages of the Kabylian and Rif types (Bourdieu 1963, p 11-12; Hart 1972, p 25). Seminomadic groups and recent sedentary farmers formed tribes with the same attributes such as common land ('arsh), military chief and sometimes council of elders (tajma'at). But its basic social unit was the faction (harfiqt in Berber and ferqa in dialectal Arabic) composed of subfractions, which in turn included several lineages, and not a village. This kind of tribes was known among the Berbers of the Aures tribal institutions and practices played a supplementary role in the village life. They protected the village society from destructive outside invasions. In the precolonial period, tribe had no permanent administration. Tribal jema' $a$ and tajma'at did not intervene into inner affairs of village communities (Daumas 1853,p 204). The sense of tribal solidarity of villagers was mobilized very rarely in cases of wars, rebellions and other important disasters. The Berber village was part of wider social and political communities.

The family was the basic social and cultural unit of the village and had many functions, not all of which were explicit. One of its roles is that it guaranteed the continuity of local "tradition" or cultural heritage of the village society; Berbers live and work more in the street than in their houses. Nowhere there is privacy in its modern. In most Berber settlements houses are built very closely. (Vladimir O. Bobrovnikov. 2000). In the everyday life the role of family and lineage preponderated that of the tribe. The tribal solidarity reinforced the common village solidarity. Extra lineage ties form new numerous relationships between households and individuals. It should be noted, that the peasant conception of the tribe was constructed on the notion of family as that of clan and village. That's why the names of Berber tribes include the notion "children, descendants" (ayt and uld in Berber and beni in dialectal Arabic) (Tillion 1938, p42-54). This kind of social and political organization of the Berbers caused a political segmentation of local society. But, on the other hand, it provided it with a strong inner autonomy based on local social and political institutions.

\subsection{Structure of Berber family}

Each nuclear family (parents and unmarried children) occupies one house. The interior of the house is carefully arranged so that each member of the family can preserve a minimum autonomy and proper privacy. The Berber family is a patriarchal one; its cohesion is protected and maintained by a system of matrimonial alliances and also by different judicial measures, for example the right of preemption, the disinheritance of women, etc., designed to conserve for the males the ownership of an undivided patrimony. It is 
therefore uncommon to find married daughters still part of the extended family. Yet the male descendants are expected to remain part of the family even after marriage, subject to the same paternal authority as before. The new wife for her part is considered as a means of increasing the size of the family and of tightening its ties. The head of the family lives with his wife, his sons and daughters-in-law, his unmarried or divorced daughters, his mother, and, generally, his brothers, in order to avoid either division of property or the building of new houses (Figure 5).
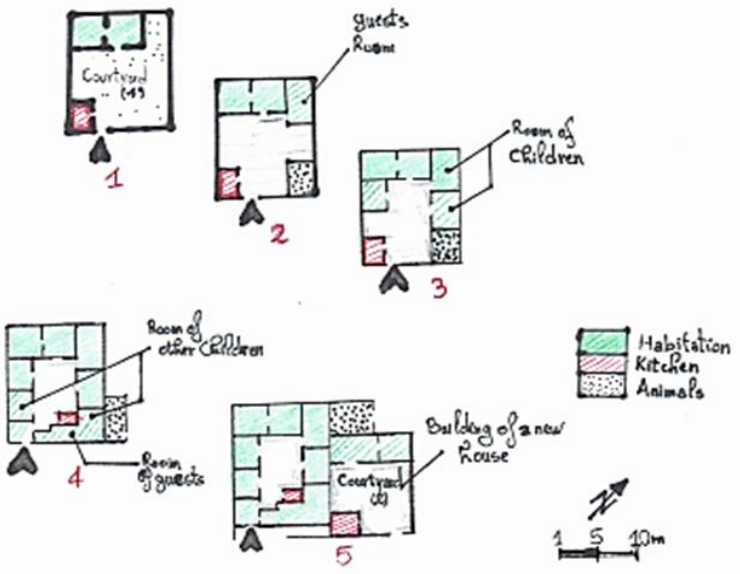

Figure 5. Evolution of a traditional house according to the Structure of Berber family (Authors developed from analysis and Marc Cote studies).

\section{House Types}

The traditional house "thaddart", like any vernacular architecture, is the result of human adaptation to climatic and social conditions and availability of construction materials and knowledge of their techniques. Indeed, it is a house of long ago in which everything was present: the best techniques, the most efficient dimensions, most effective, friendly, fertile and economical arrangements, where wisdom reigned and expressed itself through poetry. The traditional Berber house was a product of collective efforts: the house was folklore (Figure 6).

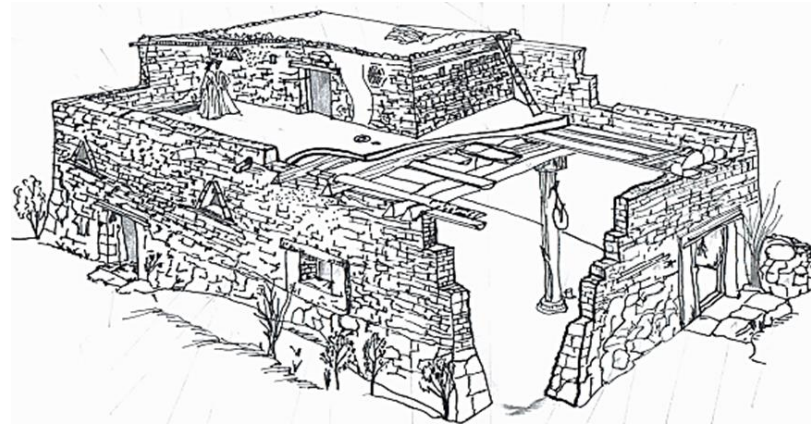

Figure 6. Traditional Berber house, sample of a typical Shawia dwelling (developed by Authors from analysis and Daniele Jemma (1989) studies)
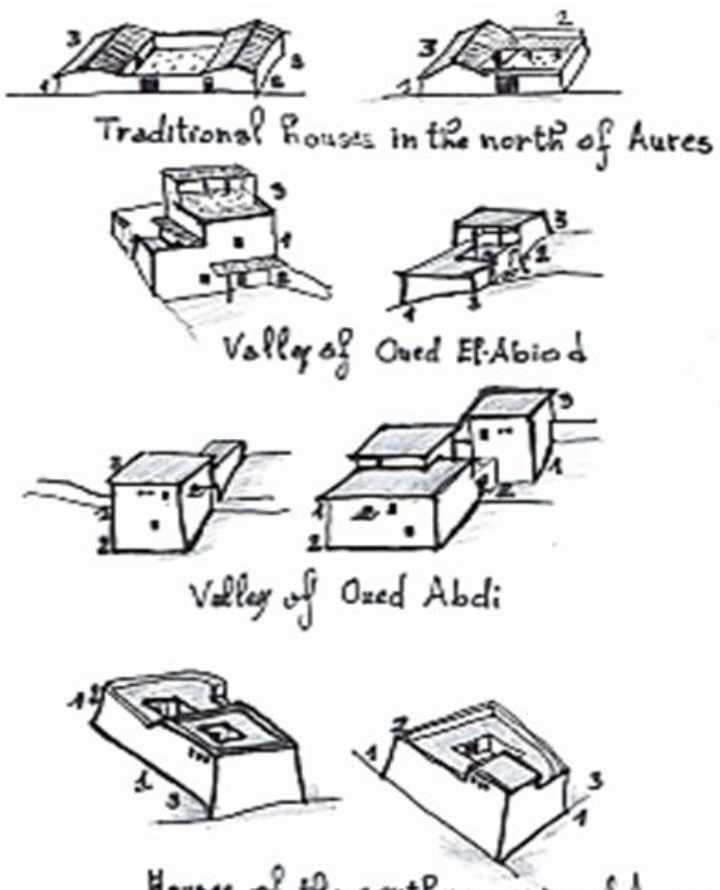

Houses of the southern region of Aures

Figure 7. Details of a Berber house types. Samia AJALI (1986).

\section{Building Process}

In the Aures valleys, as in any traditional society, the construction of a house is a great event. It is not just the result of individual initiative; both main social groups are involved in the task, the domestic group related by blood that forms the family, in which men, women and children participate, expressing the family unity in economic and social terms, and the village group that is the community. Everyone is called in, becoming thus involved in a mutual co-operative effort known as 'tuiza'.

Usually the Shawia start building their houses between April and October, in order to avoid the heavy rain and snow of the winter. The task involves two distinct phases: the preparation, when the site is selected and the materials gathered and brought to the site, the second is the operation of dwelling construction. The process of construction involves firstly an act of appropriation of the space, and secondly an act of transformation of the space. Generally the site is chosen as near as possible to the houses of parents or relatives, to tighten the clan. Traditionally the laying out is followed by a ritual ceremony, and the same procedure is repeated at every step of the construction (Figure 8). Religious ceremonial has almost always preceded and accompanied its (the house's) foundation, erection, and occupation (LEBBAL, 1989). 


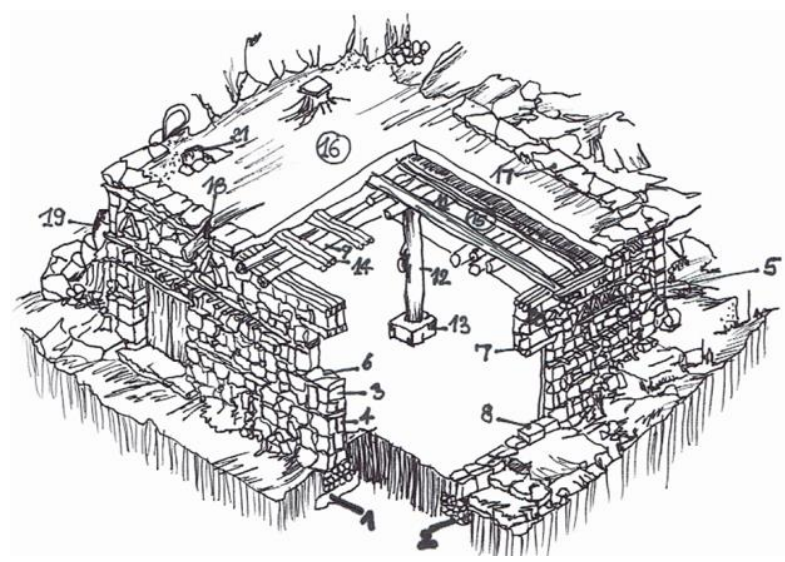

Figure 8. Details of a Berber house. Drawing from LEBBAL (1989), "Traditional Berber Architecture".

1 El-sas:foundation

2 Footings

3 Hidh: bearing walls

4 Aaqod: lacing timber

5 Hbabth:openings

6 Thaqth: windows

7 Laatbath: lintel

8 Laatbath: threshold

9 lqundasen: main beams

10 Roof structure

11 Hsasat:support

12 Hagidith

13 Hazruthon-Hagidith:padstone

14 Hikhsasban: joists

15 Hijridhin: plam stems

\section{Domestic Space's Strategies of Transformation}

According to the investigations in the agglomeration of Abdi Valley particularly in the villages of Menaa: Tigherghar, Warka and Oughanim; we have find that the most of population immigrate out the region, this is due essentially to the economic factor. Houses are more complex phenomena than accounts based on mode of construction or architectural style. The traditional architecture of the Aures people is a personal adaptation of a group solution. The houses erected by a particular society are of a style which has been communally worked out over several generations (Figure 9).

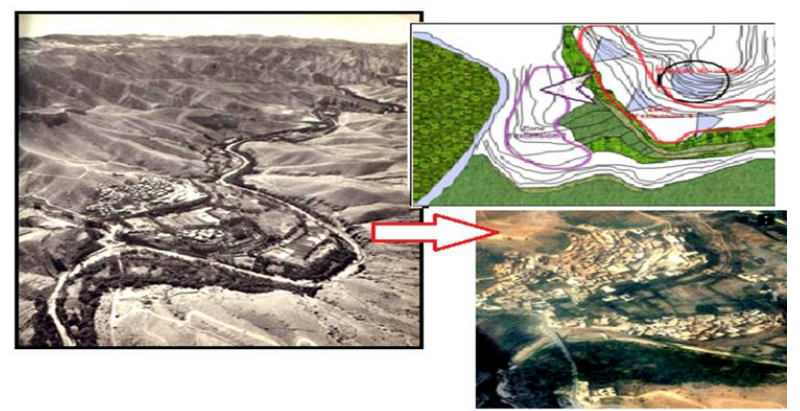

Figure 9. Example of external transformation by the use of new materials which are not local at Warka (Authors. 2015)

They constitute a synthesis of the numerous factors controlling their social and physical organization; they respond to the socio-cultural and economic imperatives that are the characteristics of the social group. The vernacular style shows a direct participation of the inhabitants in the creation of their homes, which reflect the expression of their personal and social needs (Figure 10).

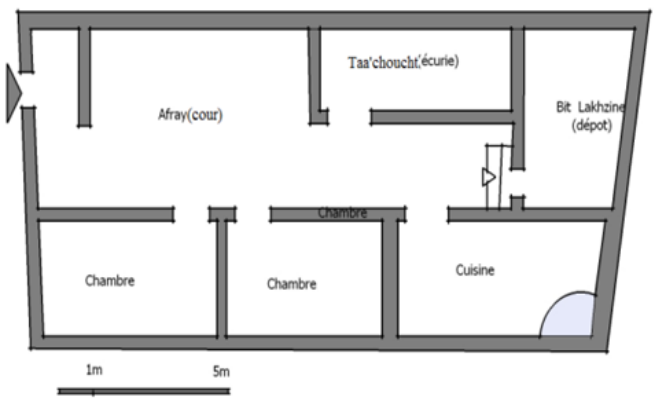

Figure 10. Example of traditional Berber house from Aoughanim. (Authors, 2016).

The appearance of the Aures settlements has however, considerably changed (Figure 11), with several western-style houses being built and several traditional ones falling into ruin. Nowadays the potential of indigenous planning and building methods are being neglected. Thus, traditional architectural forms are being progressively destroyed, due to contact with the "modern world" BENABBAS (2006).

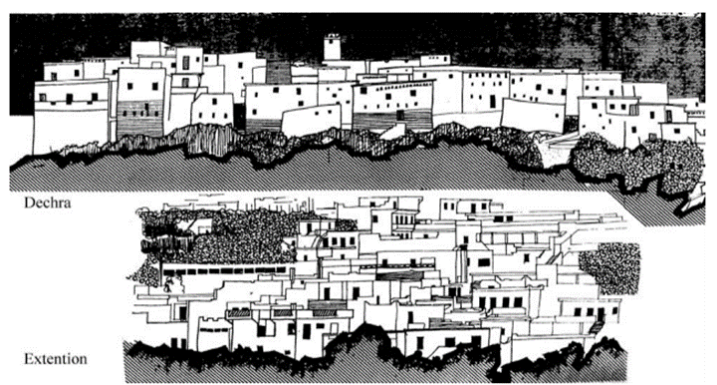

Figure 11. Transformations in the urban landscape of Menaa. BENABBAS (2006).

The interpretation of the information collected on the urban compositions of the study area, macro-structure and microstructures, as well as the socio-economic dynamics of Aures Valleys give image to the region. It made it possible to particularities of the study area and to recognize its specificities. Recognition of structures and dynamics of the Aures massif and their relations with the Plans. The interpretation can be done in terms of:

- Plans and interior domestic spaces;

- Building technology; 
- Materials and techniques used in construction;

-Types and dimensions of openings;

- General landscape and urban background of traditional Berber villages.

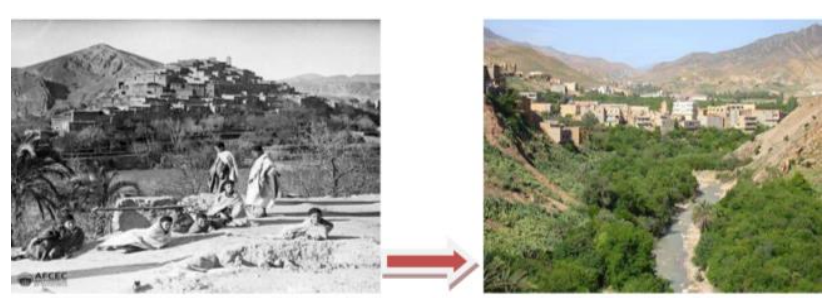

Figure 12. Example of external transformation by the use of new materials which are not local to Menaa. (Authors: Menaa between 1943 \& 2016).

\section{Process of transformation of the Berber traditional living spaces 7.1Strategies of transformation}

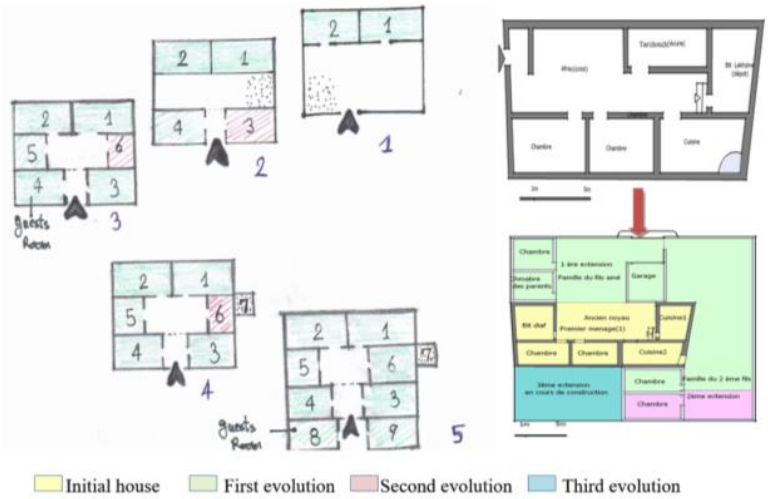

Figure 13. Two Transformation strategies and evolution of domestic spaces in Aoughanim village. Authors, 2016 (Left); 2017 (Right).

\section{2 . Examples of Structure of New Building in} the Study Case:
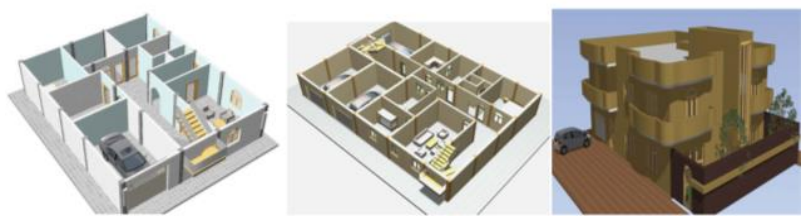

Figure 14. New House Types with New Spaces and New Materials of Construction. Saada Choukri, architect in the region of Tigharghar, Menaa. 2017

\section{Conclusions}

The traditional architecture of the Aures people is a personal adaptation of a group solution. The houses erected by a particular society are of a style which has been communally worked out over several generations. They constitute a synthesis of the numerous factors controlling their social and physical organization; they respond to the socio-cultural and economic imperatives that are the characteristics of the social group. The vernacular style shows a direct participation of the inhabitants in the creation of their homes, which reflect the expression of their personal and social needs. Traditional habitat is the simplest form of living, a profound lesson, elaborated with local materials and techniques, expressing the values and cultures of each society.

The appearance of the Aures settlements has however, considerably changed, with several western-style houses being built and several traditional ones falling into ruin. Nowadays the potential of indigenous planning and building methods are being neglected. Traditional architectural forms are being progressively destroyed due to contact with the 'modern world'. They are being replaced by western methods, often irrelevant to local conditions and needs. The indigenous architecture of the Aures constitutes a unique heritage. Definite steps should be taken to preserve it, at least in part.

Through all the Aures, the deep changes which the Aurassien society is undergoing since independence, are expressed by a spectacular transformation of the area (macrostructure), right through, in this vast mountainous mass, one sees a deeply faded vernacular architecture, sometimes with the state of ruin, and an emergence of new forms in the space.

These microstructures, often called "Dechras", are particularly revealing of this cultural duality and the absence of references. The accession to 'modernity' passes here by the assimilation of an unsuited "conveniences", even sometimes not in use. In fact, it is the reproduction or the naive transplantation of a model imported without a doctrine of integration. Despite the modernism apparent of Algerian urban population; most of Algerian society still traditional in social practices. This explains the need for new housing designs which are adapted to contemporary needs, but which still express the principal traditional requirements of daily life. Self-built housing, primarily the architectural expression of middleincome groups, has failed nowadays to address these two needs adequately. Such housing in the Berber massif is neither unique nor appropriate to Algeria. More forms of housing are likely to be developed in the near future, as Algerian look for a new typology that will better balance their requirements.

\section{Acknowledgements}

This research did not receive any specific grant from funding agencies in the public, commercial, or not-for-profit sectors. 


\section{Conflict of interests}

The authors declare no conflict of interest.

\section{References}

Adjali,S. (1986). Habitat tradtionnel dans les Aures [Traditional home in the Aures]. CNRS Editions. As cited in Annuaire de l'Afrique du Nord[ Directory of North Africa] (2002). Center for Research and Studies on Mediterranean Societies (CRESM) (Eds.). Paris.(pp. 271-280). Doi:10.4000/books.editionscnrs.817.

http://aan.mmsh.univ-aix.fr/Pdf/AAN-198625_50.pdf

Benabbas, M. (2012). Developpement urbain et architectural dans l'Aures central et choix du mode d'urbanisation[Urban and architectural development in central Aures and choice of urbanization mode]. Doctorate thesis. University of Constatine. http://bu.umc.edu.dz/theses/urbain/BEN6227. pdf

Benbouaziz. A . (2011). Les transformations architecturales et morphologiques de I'habitat traditionnel dans les Aures: Cas de Menaa. Master thesis

Architectural and morphological transformations of the traditional habitat in the Aures: Case of Menaa]. University Mohamed Khider. Biskra. Retrieved from http://thesis.univ-

biskra.dz/1125/11/Annexes.pdf.

Bernard ,A \& Doutte, E.( 1917).L'habitation rurale des indigenes de l'Algerie. In: Annales de Géographie [Annals of Geography].Vol 26, $n^{\circ} 141$. (pp. 219-228). (Original work published 1906). Daumas 1853,p 204

https://doi.org/10.3406/geo.1917.8629

Brown, F\& Bellal ,T.(2001). Comparative Analysis of M'zabite and Other Berber domestic space .Atlanta.

https://pdfs.semanticscholar.org/2c95/22d1 13 c6dc0a7c8ad65b61acf3ecee6da2a5. pdf

Colonna, F. (1987).Savants paysans. Eléments d'histoire sociale sur l'Algérie rurale[Savant peasants. Elements of social history on rural Algeria]. OPU (Ed). Algeria. ( p.356).

Émerit M., P. Bourdieu \& A. Sayad. (1964). Le déracinement: La crise de l'agriculture traditionnelle en Algérie [uprooting - The crisis of traditional agriculture in Algeria]. Collection of « Grands documents ॥Vol. 14. In: Revue du Nord [Northern Review]. Vol 47. n¹86. July september 1965. (p. 532).

https://www.persee.fr/doc/rnord_00352624_1965 num_47_186_2542_†1_0532_0000_1

Kamalipour, H. and Zaroudi, M. (2014) Sociocultural Context and Vernacular Housing
Morphology: A Case Study. Current Urban Studies, 2, 220-232.

Doi: 10.4236/cus.2014.23022.

Meghraoui chouguiat.N.(2011). Trois jours aux...Aures[Three days in...Aures]. Algeria. Dalimen. Cited from Tillion 1938, p42-54

Messaci .N (2005). L'espace montagnard entre mutations et permanences [ The mountain space between mutations and permanences]. centre de recherche en anthropologie sociale et culturelle [center of research in social and cultural anthropology]. Algeria.

Lebbal N. (1989). Traditional Berber Architecture in the Aures. Algeria.

Vernacular Architecture. 20:1. (pp.24-37). http://dx.doi.org/10.1179/vea.1989.20.1.24

Pinson, D. (1990). Habitat contemporain au Maroc: tradition affichée et tradition engrammée. In Maghreb, patrimoine, tradition et mdernité [Contemporary habitat in Morocco: displayed tradition and engrammed tradition. In Maghreb, heritage, tradition and modernity] Paris. Publisud.( pp. 113-125).

Rapoport. A. (1969). House Form and Culture (Englewood Cliffs, N. J. Prentice-Hall). Retrieved

from http://www.fastonline.org/CD3WD_40/JF /433/25-603.pdf

Vladimir O. Bobrovnikov. (2000). The Berbers (early 19th $20^{\text {th }}$ centuries $A D$ ). In "The Civilizational Dimension" Series. Institute for African Studies of the Russian Academy of Sciences. Moscow. Retrieved from

http://www.inafran.ru/en/sites/default/files/page _file/civilizational_models_of_politogenesis.pdf \#page $=211$.

Wacquant, L. (2004). Following Pierre Bourdieu into the field. Sage Journals.Vol 5, Issue 4, first Published Decemberl. https://doi.org/10.1177/1466138104052259 